the Third Congress of Prebistorians of the Far East, ed. by F. N. Chasen and M. W. F. Tweedie, pp. 194-99. Singapore: Government Printing Office.

Gorman, Chester. 1971. "The Hoabinhian and After: Subsistence Patterns in Southeast Asia during the late Pleistocene and Early Recent Periods." World Archaeology 2, no. 3: 300-320.

Linehan, W. 1968. "A Neolithic Link between North Pahang, Malaya and the Sino-Mongolian Border." In Anthropology at the Eighth Pacific Science Congress, ed. by Wilhelm G. Solheim II, pp. 96-101. Asian and Pacific Archaeology Series, No. 2. Honolulu: Social Science Research Institute, University of Hawaii.

Loewenstein, J. 1958. “The Eskimo Ulu in Malayan Neolithic." Man 58: 37-40. Skinner, Henry D. 1968. "The North Pacific Origin of Some Elements of Polynesian Material Culture." In Anthropology at the Eighth Pacific Science Congress, ed. by Wilhelm G. Solheim II, pp. 102-111. Asian and Pacific Archaeology Series, No. 2. Honolulu: Social Science Research Institute, University of Hawaii.

Solheim, Wilhelm G., II. 1980. "Searching for the Origins of the Orang Asli." Federation Museums Journal 25 (n.s.): 61-75.

\title{
On Review of The Role of the Sangha in Modern Thailand
}

Donald Swearer's review of my book The Role of the Sangha in Modern Thailand (41, no. 4 [1982]: 883-85) contains several misrepresentations.

By collecting 200 of my 300 questionnaires from the provinces of Chiang Mai, Udornthani and other parts of the country, I did avoid urban slant.

The geographical outlay of Wat Bovoranives served as the starting point for the discussion of a monastic environment and how it is shaped, changed, or preserved by individual abbots and monks in interaction with the laity (as stated on p. 119 and summarized on p. 139). Wat Bovoranives showed historically and functionally most of the features a Thai monastary can have. It could thus easily be compared with other wats in Bangkok, wats as community centers, missionary, meditation, and nonTheravāda wats.

The book contains 449 footnotes, a 35-page glossary, and a 30-page bibliography. Don't we all wish we could add more footnotes and more references?

The chapter on basic tenets in Thai Buddhism describes in equal length the development of Thai world views as it surveys motivational or behavioral themes. The survey is based on more than three secondary sources; in fact, it contains the summary of several years of participant observation.

The reviewer apparently failed to read the summaries of my findings throughout the book. For example, after I had travelled extensively throughout Thailand, after I had spoken to and even taught several hundred monks (in addition to the monks who volunteered to fill out my questionnaire), and after I had interviewed over two hundred laymen and laywomen from all socioeconomic groups, I was facing a wide range of opinions about who is considered an ideal monk - a monk who "keeps Dhamma alive" and stays in his monastery available for those who "request" his help, a monk who goes out to actively participate in solving the problems of his community, or a monk who gets involved in the political process (e.g., pp. 149, 198). Buddhism may be in transition in the heads of some people, but the tendency to preserve Buddhist ideas and institutions (p. 195) strongly prevailed during 1971-1974 when I conducted my fieldwork and wrote the book. 
My book is the reaction to a controversy. For years renowned scholars could not agree whether Thai society was or was not loosely structured. I did not want to fall into the trap of subjective and premature analyses and assessment on the basis of insufficient data, insufficient either with respect to quantity and quality or being collected only in one area with no correlation to conditions in other areas. I wanted to collect a wide range of solid data to prove the complexity of my topic and to gain a sound basis for future analysis. I accomplished this survey in one year. On the first and last page of my book, I stated clearly why I wanted to write a descriptive study. Swearer, who could not find fault with any of my factual statements, ignores my expressed intent and refuses to review the book on its own grounds.

Ruth-Inge Heinze University of California, Berkeley 